\title{
Antithrombotic treatment during coronary angioplasty after failed thrombolysis: strategies and prognostic implications. Results of the RESPIRE registry
}

José M. De la Torre Hernández ${ }^{1 *}$, Mario Sadaba Sagredo², Miren Telleria Arrieta ${ }^{3}$, Federico Gimeno de Carlos ${ }^{4}$, Elena Sanchez Lacuesta ${ }^{5}$, Juan A. Bullones Ramírez ${ }^{6}$, Javier Pineda Rocamora, Victoria Martin Yuste ${ }^{8}$,

Tamara Garcia Camarero ${ }^{1}$, Mariano Larman ${ }^{3}$ and Jose R. Rumoroso ${ }^{2}$

\begin{abstract}
Background: Thrombolysis is still used when primary angioplasty is delayed for a long time, but 25\%-30\% of patients require rescue angioplasty (RA). There are no established recommendations for antithrombotic management in RA. This registry analyzes regimens for antithrombotic management.

Methods: A retrospective, multicenter, observational registry of consecutive patients treated with RA at 8 hospitals. All variables were collected and follow-up took place at 6 months.

Results: The study included 417 patients. Antithrombotic therapy in RA was: no additional drugs 22.3\%, unfractionated heparin (UFH) 36.6\%, abciximab 15.5\%, abciximab plus UFH 10.5\%, bivalirudin 5.7\%, enoxaparin 4.3\%, and others $4.7 \%$. Outcomes at 6 months were: mortality 9.1\%, infarction 3.3\%, definite or probable stent thrombosis $4.3 \%$, revascularization $1.9 \%$, and stroke $0.5 \%$. Mortality was related to cardiogenic shock, age $>75$ years, and anterior location. The stent thrombosis rate was highest with bivalirudin (12.5\% at 6 months). The incidence of bleeding at admission was high (14.8\%), but most cases were not severe (82\% BARC $\leq 2)$. Variables independently associated with bleeding were: femoral access (OR 3.30; $95 \% \mathrm{Cl}$ 1.3-8.3: $p=0.004)$ and post-RA abciximab infusion (OR 2.26; 95\% Cl 1.02-5: $p=0.04$ ).
\end{abstract}

Conclusions: Antithrombotic treatment regimens in RA vary greatly, predominant strategies consisting of no additional drugs or UFH $70 \mathrm{U} / \mathrm{kg}$. No regimen proved predictive of mortality, but bivalirudin was related to more stent thrombosis. There was a high incidence of bleeding, associated with post-RA abciximab infusion and femoral access.

Keywords: Acute myocardial infarction, Thrombolytic therapy, Angioplasty, Anticoagulation

\section{Background}

Primary angioplasty is the treatment of choice in acute myocardial infarction if it can be performed within 120 min of first medical contact. Fibrinolysis is recommended in patients who have no contraindications if primary angioplasty cannot be performed within $120 \mathrm{~min}$

\footnotetext{
* Correspondence: he1thj@humv.es; chematorre60@gmail.com

'Servicio de Cardiología, Unidad de Hemodinámica y Cardiología Intervencionista, Hospital Universitario Marqués de Valdecilla, Valdecilla Sur, 1a Planta, 39008 Santander, Spain

Full list of author information is available at the end of the article
}

of first medical contact $[1,2]$. This time shortens to $90 \mathrm{~min}$ in the case of infarctions less than two hours old with extensive territory at risk (anterior infarction). A potential indication for fibrinolysis might be patients presenting within three hours of symptom onset, in whom primary angioplasty cannot be performed within the first $60 \mathrm{~min}$. Fibrinolysis is effective in these patients, albeit at the cost of a slight increase in intracranial bleeding [3]. However, in $25 \%-30 \%$ of cases fibrinolysis fails to achieve reperfusion, and patients have to undergo urgent catheterization and rescue angioplasty (RA) $[4,5]$. 
This has been shown to improve the prognosis compared with a conservative approach or repeat fibrinolysis [6-9].

Patients who require RA are exposed to various antiplatelet drugs and anticoagulants, as well as previous fibrinolytic therapy, which explains the high risk of bleeding observed, of up to 25\% [6-9]. Clinical guidelines contain no clear regimens or specific recommendations for the management of antithrombotic therapy in RA $[1,2,9]$.

This rescue angioplasty registry was a multicenter observational study designed to analyze the different antiplatelet and anticoagulation regimens used during the procedure and, more importantly, the ischemic and bleeding complications associated with them.

\section{Methods}

The RESPIRE (Registro ESpañol de anticoagulacion en angioPlastla de REscate) registry is a multicenter prospective study involved 8 Spanish hospitals. All consecutive patients who underwent RA following failed fibrinolysis between January 2012 and December 2013 were included in the study.

The decision to proceed to RA was made by the physicians in charge of each particular case. In general, however, it was indicated after failed fibrinolysis, defined as $<50 \%$ reduction in ST elevation $60 \mathrm{~min}$ after administration of the fibrinolytic, with or without chest pain. Presentation in cardiogenic shock was not excluded.

All data were entered into an anonymized database, including past cardiovascular history, clinical data, CRUSADE bleeding score, details of the procedure, and events at discharge and one and six months postprocedure. The registry was approved by the respective ethics committees of the participating centers and was in compliance with the Helsinki Declaration.

\section{Study endpoints and definitions}

Major adverse cardiac events were defined as follows: a) death as all-cause mortality; b) cardiac death as mortality due to heart conditions such as infarction, heart failure or stent thrombosis, including sudden death of undefined origin; c) myocardial infarction (MI) if detailed criteria were met. The criteria for MI were: 1) detecting a rise and fall in cardiac biomarkers (preferably troponin) with at least one value above the 99th percentile upper reference limit, together with signs of myocardial ischemia with at least one of the following symptoms: chest pain, electrocardiographic abnormalities (new-onset ST-T changes or new-onset left bundle branch block) or onset of pathological Q waves, new-onset regional wall motion or perfusion abnormalities; 2) sudden death with cardiac arrest, often preceded by symptoms suggestive of ischemia, accompanied by ST elevation of presumably new onset or new-onset left bundle branch block, or angiographic or post-mortem evidence suggesting recent thrombus (if death occurred before blood samples could be obtained or before cardiac markers appeared in the blood); and 3) pathological signs of acute infarction. Revascularization was defined as any angioplasty procedure or coronary revascularization surgery. Stent thromboses were classified according to the Academic Research Consortium (ARC) classification, and bleeding was categorized in accordance with the Bleeding Academic Research Consortium (BARC) classification $[10,11]$.

Table 1 Clinical characteristics

\begin{tabular}{|c|c|}
\hline & $N=417$ \\
\hline Age (years) & $61.6 \pm 12$ \\
\hline Females & 59 (14.1\%) \\
\hline Weight (kg) & $80 \pm 12.8$ \\
\hline Height (cm) & $169.4 \pm 7.6$ \\
\hline Hypertension & $208(50)$ \\
\hline Diabetes & $86(20.6)$ \\
\hline Smoking & $242(58)$ \\
\hline Dyslipidemia & $192(46)$ \\
\hline Previous stroke & $17(4)$ \\
\hline Peripheral vascular disease & $17(4)$ \\
\hline Previous infarction & $41(9.8)$ \\
\hline HR at admission (bpm) & $76.9 \pm 19.2$ \\
\hline SBP at admission (mmHg) & $124.8 \pm 27.1$ \\
\hline Creatinine (mg/dL) & $0.99 \pm 0.5$ \\
\hline Baseline hematocrit (\%) & $40 \pm 8.6$ \\
\hline Ejection fraction (\%) & $49.3 \pm 12.2$ \\
\hline \multirow[t]{2}{*}{ Pain onset to thrombolysis (minutes) } & $147 \pm 111$ \\
\hline & $115(80-175)$ \\
\hline \multirow[t]{2}{*}{ Thrombolysis to PCI (minutes) } & $219 \pm 165$ \\
\hline & $170(132-244)$ \\
\hline \multicolumn{2}{|l|}{ Thrombolytic regimen } \\
\hline TNK-tPA + enoxaparin & $391(93.7)$ \\
\hline TNK-tPA + fondaparinux & $21(5)$ \\
\hline TNK-tPA + unfractionated heparin & $5(1.2)$ \\
\hline \multicolumn{2}{|l|}{ Pre-RA Killip class } \\
\hline Killip I & $318(76.2)$ \\
\hline Killip ॥ & $48(11.5)$ \\
\hline Killip III & $17(4.1)$ \\
\hline Killip IV & $34(8.2)$ \\
\hline
\end{tabular}

Qualitative variables are shown as $\mathrm{n}(\%)$ and quantitative variables as mean \pm standard deviation, but times are also shown as median and interquartile range

$H R$ heart rate, $P C I$ percutaneous coronary intervention, $S B P$ systolic blood pressure, TNK-tPA tenecteplase, UFH unfractionated heparin 


\section{Statistical analysis}

Continuous parameters are expressed as mean \pm standard deviation or median (interquartile range). Categorical variables are reported as percentages. Categorical variables were compared using the chi-square test or Fisher's exact test. A Kolmogorov-Smirnov test was performed to evaluate the normal distribution of continuous variables. Continuous variables were compared using ANOVA or the Kruskall-Wallis test, depending on their distribution. A multivariate logistic regression model was constructed to establish independent predictors of events during hospitalization. Statistical analysis was two-tailed, and statistical significance was taken as $p<0.05$. Analysis was performed using the statistical package SPSS 15.0.

\section{Results}

Four hundred and seventeen consecutive patients with acute myocardial infarction who underwent RA were included. Their clinical features are described in Table 1 . Elapsed time between thrombolysis and RA was $219 \pm 165$ min with a median of 170 (IQ range 132244). The pre-catheterization thrombolysis and anticoagulation regimen was, with few exceptions, tenecteplase (TNK-tPA) plus enoxaparin, and the pre-catheterization antiplatelet regimen was aspirin plus clopidogrel $300 \mathrm{mg}$ in the vast majority of cases (85.6\%). Most patients (88.5\%) had a CRUSADE score of less than 40 (Fig. 1).

Table 2 shows the approach used for catheterization and the antithrombotic regimen used to perform RA. The anticoagulation regimens used during the procedure varied greatly, but consisted predominantly of not using any additional drugs or using unfractionated heparin (UFH) at $70 \mathrm{U} / \mathrm{kg}$. IIb/IIIa receptor inhibitors (abciximab) were used alone or in combination with UFH in $26 \%$ of patients, with or without post-procedural infusion. Table 2 also shows pre- and post-RA flow status. It should be noted that $43 \%$ had a TIMI flow of 2 or 3 when the procedure started, and TIMI flow 3 had been achieved in $89.4 \%$ of patients when it ended.

Table 3 shows the various subgroups according to antithrombotic treatment regimen. Significant differences exist for many of the variables examined. Younger patients were treated with abciximab alone, and patients of lower body weight received no additional therapy. This subgroup, in whom no new antithrombotic drugs were added, included patients with higher systolic blood pressure and higher creatinine values. The longest delay between thrombolysis and RA was seen in the subgroup treated with UFH plus abciximab. As regards the procedure, radial access was uncommon in patients given no additional therapy and those treated with abciximab alone. Baseline coronary flow was more conserved in patients with no additional therapy, and less so in those treated with combined UFH and abciximab. Flow restoration was consequently somewhat less successful in the latter group, and more stents had to be implanted. These data indicate regimen selection on the basis of baseline flow status (thrombus burden) and bleeding risk profile. The prescribed time period for dual antiplatelet therapy was 12 months in all patients but no data on compliance was available.

The 6-month events rate in the overall population is shown in Table 4. The procedure mortality rate was $2.4 \%$, and the in-hospital mortality rate $7.4 \%$. As bleeding was the most common event, and is particularly important in this context, a detailed classification of bleeding that occurred during hospitalization is shown in Table 5. The vast majority of bleeding events were not severe, but 11 (2.6\%) high-grade bleeding episodes

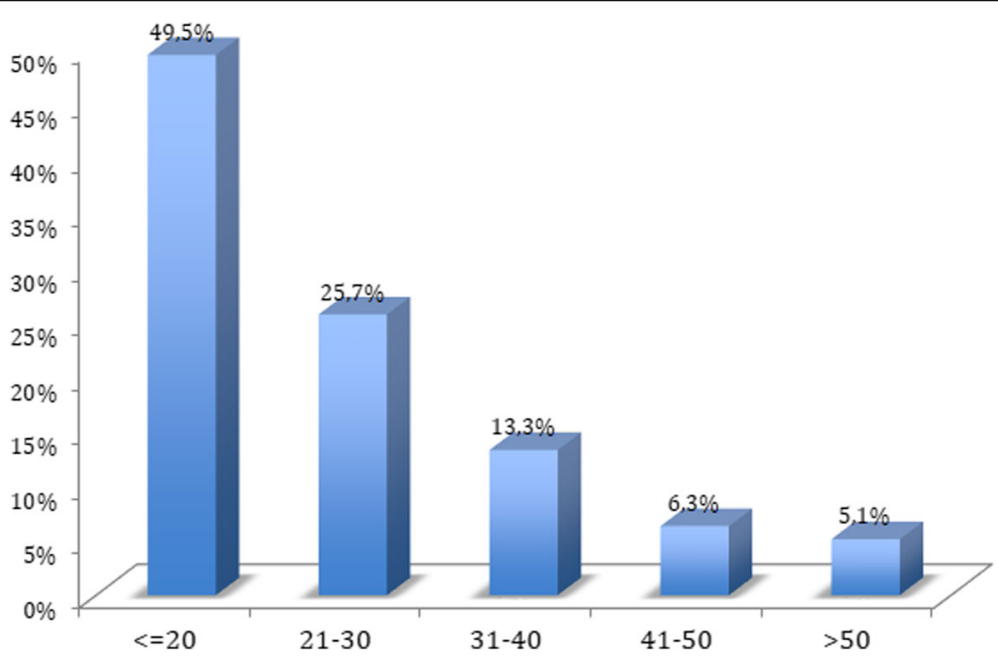

Fig. 1 CRUSADE bleeding score in the study population 
Table 2 Procedural characteristics: access site, antithrombotic therapy, and arterial flow status

\begin{tabular}{|c|c|c|}
\hline & & $N=417$ \\
\hline Femoral access & & $217(52)$ \\
\hline Radial access & & $200(48)$ \\
\hline \multicolumn{3}{|l|}{ Antithrombotic therapy } \\
\hline No additional treatment & & $93(22.3)$ \\
\hline UFH & & $153(36.6)$ \\
\hline UFH 70 U/kg & 115 & \\
\hline UFH 100 U/kg & 38 & \\
\hline Enoxaparin & & $18(4.3)$ \\
\hline Enoxaparin 0.35 mg/kg & 3 & \\
\hline Enoxaparin 0.5 mg/kg & 15 & \\
\hline Bivalirudin & & $24(5.7)$ \\
\hline Bivalirudin in cath lab & 10 & \\
\hline Bivalirudin in cath lab $+4 \mathrm{~h}$ & 14 & \\
\hline Abciximab & & $65(15.5)$ \\
\hline Abciximab bolus & 12 & \\
\hline Abciximab bolus plus infusion & 53 & \\
\hline Abciximab plus UFH & & $44(10.5)$ \\
\hline Abciximab bolus & 18 & \\
\hline Abciximab bolus plus infusion & 26 & \\
\hline Other regimens & & $20(4.7)$ \\
\hline \multicolumn{3}{|l|}{ Baseline flow } \\
\hline TIMI 0 & & $196(47)$ \\
\hline TIMI 1 & & $44(10.5)$ \\
\hline TIMI 2 & & $66(15.8)$ \\
\hline TIMI 3 & & 111 (26.6) \\
\hline \multicolumn{3}{|l|}{ Final flow } \\
\hline TIMI 0 & & $13(3.1)$ \\
\hline TIMI 1 & & $9(2.2)$ \\
\hline TIMI 2 & & $22(5.3)$ \\
\hline TIMI 3 & & 373 (89.4) \\
\hline
\end{tabular}

UFH unfractionated heparin

(BARC $>2$ ) occurred. The risk of BARC $>1$ bleeding was significantly higher with the femoral approach than with radial access: $13.7 \%$ versus $4.3 \%(p=0.001)$. Most patients had a low initial bleeding risk based on their CRUSADE score, as shown in Fig. 1. The CRUSADE score was not correlated with the incidence of BARC $>1$ bleeding, as illustrated in Fig. 2.

Clinical outcome by treatment subgroup is shown in Table 6, which lists all events detected in 6 months. There were no differences in mortality, although this tended to be higher in the group treated with combination UFH plus abciximab, most likely because this group had more adverse features, as mentioned above.
The incidence of infarction and thrombosis was significantly higher in the bivalirudin group. As regards bleeding, patients treated with abciximab alone had a significantly higher risk, probably because of a lower rate of radial access use (17\%) and greater use of postprocedure infusion (81.5\%). These values were $70.4 \%$ and $59 \%$ respectively in the abciximab plus UFH group. The bleeding rate in the group given an abciximab bolus but no infusion was notably lower, in numerical terms, than in patients given a bolus plus infusion (BARC $>1$ of $10 \%$ versus $15 \%$, and BARC $>2$ of $3.3 \%$ versus $6.3 \%$ ), and there were fewer ischemic events ( $0 \%$ thrombosis/ infarction rate versus $7.5 \%$ ).

In multivariate analysis for predictors of BARC $>1$ bleeding, femoral access and post-RA abciximab infusion were identified as predictors, and a strong trend was seen for age $>75$ years (Table 7). The higher bleeding risk conferred by post-RA abciximab infusion was very obvious in the case of femoral access (24\% BARC $>1$ bleeding), but not if the radial approach was used (4\%).

Table 8 shows the variables found to be independent predictors of mortality, which were cardiogenic shock, age $>75$ years, and anterior infarction.

\section{Discussion}

The main findings of the RESPIRE registry are: a) The thrombolysis regimen, and the antiplatelet and anticoagulation regimens associated with it, were fairly standardized; b) There was a long delay between thrombolysis and RA; c) RA did not employ radial access in most cases, even though the increased bleeding risk in these patients is well known; d) The anticoagulation and antiplatelet regimens used in RA varied markedly, with a predominance of no additional drugs or $\mathrm{UFH}$ at $70 \mathrm{U} / \mathrm{kg}$; e) Abciximab was used in just over a quarter of patients; f) Mortality was relatively higher than in primary angioplasty series, and was related to cardiogenic shock, age $>75$ years, and anterior infarction; g) The incidence of bleeding was high, but most bleeding episodes were not severe; post-RA abciximab infusion and femoral access were associated with greater bleeding risk.

The superiority of primary angioplasty over fibrinolysis when performed soon enough is well established. Infarction care systems based on primary angioplasty have managed to reduce the overall mortality rate substantially, not just because of the advantages of primary angioplasty, but also due to the consequent large reduction in the non-reperfusion rate $[1,2]$. Despite this, fibrinolytic therapy is still required in a certain proportion of patients, specifically those presenting at sites with no catheterization laboratory, and in whom the estimated time to primary angioplasty exceeds $120 \mathrm{~min}$. Nevertheless, thrombolysis is associated with a reperfusion failure 
Table 3 Clinical features and procedural characteristics by antithrombotic treatment group

\begin{tabular}{|c|c|c|c|c|c|c|c|}
\hline & $\begin{array}{l}\text { Nothing } \\
n=93\end{array}$ & $\begin{array}{l}\text { UFH } \\
n=153\end{array}$ & $\begin{array}{l}\text { UFH }+ \text { Abcx } \\
n=44\end{array}$ & $\begin{array}{l}\text { Abcx } \\
n=65\end{array}$ & $\begin{array}{l}\text { Bivalirudin } \\
n=24\end{array}$ & $\begin{array}{l}\text { Enoxaparin } \\
n=18\end{array}$ & $p$ \\
\hline Age (years) & $61 \pm 13$ & $60.3 \pm 14$ & $61.3 \pm 11$ & $55.4 \pm 4$ & $61 \pm 11$ & $63.9 \pm 9$ & $<0.001$ \\
\hline Females & $15(16)$ & $21(13.7)$ & $6(13.6)$ & $7(10.7)$ & $1(4.2)$ & $4(22)$ & 0.2 \\
\hline Weight (kg) & $77.5 \pm 10$ & $81 \pm 13$ & $81 \pm 12$ & $80 \pm 13$ & $81 \pm 12$ & $81 \pm 17$ & 0.01 \\
\hline Hypertension & $51(54.8)$ & $74(48.3)$ & $18(40.9)$ & $30(46)$ & $14(58.3)$ & $9(50)$ & 0.2 \\
\hline Smoking & $50(53.7)$ & $81(53)$ & $24(54.5)$ & $43(66)$ & $17(70.8)$ & $9(50)$ & 0.1 \\
\hline Diabetes & $23(24.7)$ & $34(22.2)$ & $3(6.8)$ & $13(20)$ & $4(16.6)$ & $5(27.7)$ & 0.04 \\
\hline Dyslipidemia & $47(50.5)$ & $69(45)$ & $15(34)$ & $31(47.6)$ & $15(62.5)$ & $8(44)$ & 0.03 \\
\hline Previous stroke & $3(3.2)$ & $8(5.2)$ & $1(2.2)$ & $2(3)$ & 0 & $1(5.5)$ & 0.5 \\
\hline Previous infarction & $7(7.5)$ & $14(9.1)$ & $1(2.2)$ & $11(16.9)$ & $4(16.6)$ & $3(16.6)$ & 0.03 \\
\hline Peripheral vascular disease & $5(5.4)$ & $6(3.9)$ & $2(4.5)$ & $1(1.5)$ & $1(4.2)$ & $1(5.5)$ & 0.05 \\
\hline Coronary surgery & $1(1)$ & $2(1.3)$ & 0 & $1(1.5)$ & 0 & 0 & 0.4 \\
\hline SBP at admission (mmHg) & $135 \pm 28$ & $123 \pm 27$ & $117 \pm 22$ & $127 \pm 24$ & $113 \pm 30$ & $120 \pm 24$ & $<0.001$ \\
\hline HR at admission (bpm) & $78 \pm 19$ & $77.5 \pm 19$ & $75.7 \pm 19$ & $79 \pm 20$ & $74 \pm 19$ & $67 \pm 15$ & 0.02 \\
\hline Creatinine (mg/dL) & $1.1 \pm 0.6$ & $0.9 \pm 0.3$ & $1 \pm 1$ & $1 \pm 0.3$ & $0.9 \pm 0.2$ & $1 \pm 0.2$ & $<0.001$ \\
\hline Baseline hematocrit (\%) & $40 \pm 10$ & $41.5 \pm 5$ & $41 \pm 6$ & $37 \pm 12$ & $40.8 \pm 7$ & $38.3 \pm 11$ & $<0.001$ \\
\hline Anterior infarction & $50(53.7)$ & $62(40.5)$ & $22(50)$ & $31(47.6)$ & $11(45.8)$ & $9(50)$ & 0.05 \\
\hline Ejection fraction (\%) & $46.6 \pm 11$ & $50.8 \pm 12$ & $51 \pm 14$ & $47 \pm 13$ & $50 \pm 13$ & $50.7 \pm 11$ & 0.02 \\
\hline Pain onset to thrombolysis & 120 & 121 & 105 & 105 & 120 & 88 & 0.09 \\
\hline Thrombolysis to rescue & 167 & 164 & 205 & 168 & 182 & 175 & 0.003 \\
\hline TNK-tPA + enoxaparin & 89 (95.6) & 144 (94) & $39(88.6)$ & $60(92.3)$ & $21(87.5)$ & $17(94.4)$ & 0.2 \\
\hline Killip class III-IV & $12(13)$ & $12(7.8)$ & $5(11.4)$ & $11(17)$ & $5(20.8)$ & 0 & 0.08 \\
\hline Radial access & $19(20.4)$ & $100(65.3)$ & $31(70.4)$ & $11(17)$ & $11(45.8)$ & $17(94.4)$ & $<0.001$ \\
\hline Baseline TIMI & $1.7 \pm 1.3$ & $1.4 \pm 1.3$ & $0.57 \pm 1$ & $0.78 \pm 1$ & $0.75 \pm 1.2$ & $16 \pm 1.3$ & $<0.001$ \\
\hline Final TIMI & $2.8 \pm 0.7$ & $2.9 \pm 0.5$ & $2.75 \pm 0.7$ & $2.7 \pm 0.6$ & $2.8 \pm 0.6$ & $3 \pm 0$ & 0.01 \\
\hline Baseline TIMI 0-1 & $38(40.8)$ & $77(50.3)$ & $36(81.8)$ & $45(69.2)$ & $18(75)$ & $6(33.3)$ & $<0.001$ \\
\hline Final TIMI 3 & $86(92.5)$ & $143(93.4)$ & $35(79.5)$ & $51(78.4)$ & $22(91.6)$ & $18(100)$ & 0.003 \\
\hline Thrombus aspiration & $23(24.7)$ & $56(36.6)$ & $28(63.6)$ & $38(58.4)$ & $13(54.2)$ & $6(33.3)$ & 0.001 \\
\hline Number of stents & $1.2 \pm 0.6$ & $1.3 \pm 0.7$ & $1.37 \pm 0.9$ & $1.27 \pm 0.8$ & $1.08 \pm 0.6$ & $1.1 \pm 0.5$ & 0.1 \\
\hline Multivessel disease & $41(44)$ & $48(31.4)$ & $18(40.9)$ & $27(41.5)$ & $13(54.2)$ & $8(44)$ & 0.04 \\
\hline 2nd PCl & $7(7.5)$ & $18(11.7)$ & $7(16)$ & $6(9.2)$ & $5(20.8)$ & 0 & 0.1 \\
\hline Clopidogrel load 300 mg & $85(91.4)$ & $126(82.3)$ & $37(84)$ & 55 (84.6) & $19(79.2)$ & $11(61)$ & 0.002 \\
\hline
\end{tabular}

Qualitative variables are shown as $\mathrm{n}(\%)$ and quantitative variables as mean \pm standard deviation, except times, which are shown as medians

$A b c x$ abciximab, $H R$ heart rate, $P C I$ percutaneous coronary intervention, SBP systolic blood pressure, TNK-tPA tenecteplase, UFH unfractionated heparin

Table 4 Events at 6 months

\begin{tabular}{ll}
\hline & $n=417$ \\
\hline Death & $38(9.1 \%)$ \\
Cardiac death & $33(7.9 \%)$ \\
Infarction & $14(3.3 \%)$ \\
Definite/probable thrombosis & $18(4.3 \%)$ \\
BARC >1 bleeding & $40(9.6 \%)$ \\
BARC >2 bleeding & $14(3.3 \%)$ \\
Brain hemorrhage & $5(1.2 \%)$ \\
Revascularization & $8(1.9 \%)$ \\
Stroke & $2(0.5 \%)$ \\
\hline
\end{tabular}

Table 5 Bleeding during hospitalization

\begin{tabular}{ll}
\hline BARC 1 & $N=62$ \\
BARC 2 & $26(6.2)$ \\
BARC 3a & $25(6.0)$ \\
BARC 3b & $2(0.5)$ \\
BARC 3c & $2(0.5)$ \\
BARC 4 & $4(0.9)$ \\
BARC 5 & $1(0.2)$ \\
\hline
\end{tabular}




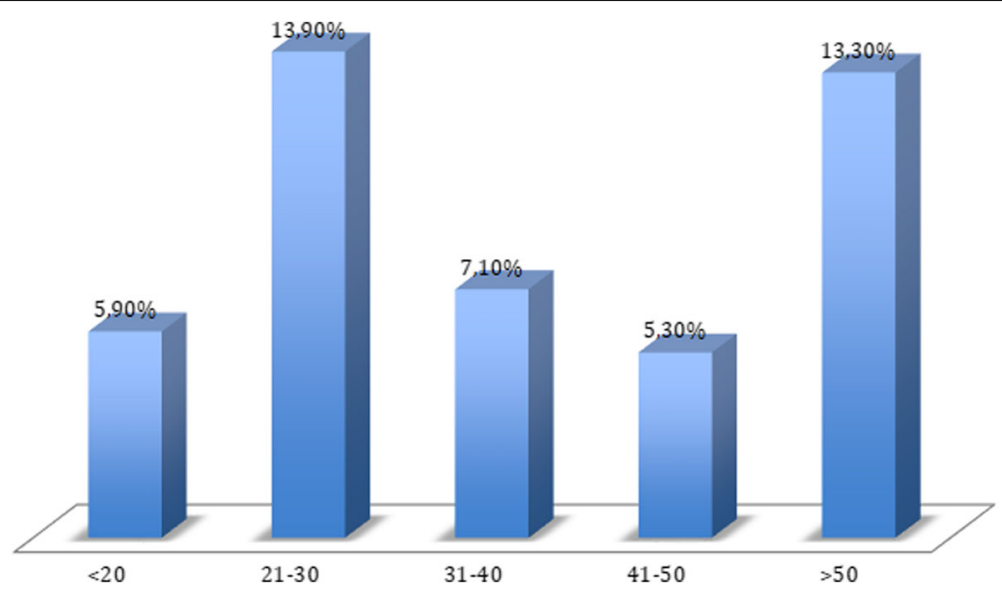

Fig. 2 BARC $>1$ bleeding rate according to CRUSADE bleeding score

rate and a certain early reocclusion rate. The proportion of patients requiring RA is about $25 \%-30 \%[4,5]$. The indication for RA in these cases is well established, because of the advantages it provides in terms of patient prognosis, compared with a conservative approach or repeat fibrinolysis [6-8].

The scenario of rescue angioplasty after fibrinolysis involves an unresolved thrombotic event and high bleeding risk because of previously administered antiplatelet, anticoagulant and thrombolytic therapy. There are no indications or recommendations in the guidelines regarding technical details or antithrombotic therapy as an adjunct to RA. The guidelines establish antithrombotic regimens for patients receiving fibrinolysis, but not for those undergoing rescue angioplasty [1, 2, 9]. This absence of recommendations for interventions of this type is due to a lack of evidence from trials, with only registries of limited size available.

With regard to access site choice, a large RA registry in the United States reported a low rate of radial access use $(14.2 \%)$. In propensity-matched analysis, the radial approach was associated with a significantly lower bleeding risk, with no influence on mortality [12].

In this respect, studies evaluating the safety of administering IIb/IIIa inhibitors (especially abciximab) are particularly worthy of note. One of these was a small randomized study involving 89 patients who underwent RA, 44 treated with abciximab and 45 not [13]. The 6-month results showed a lower incidence of events in the treated group, with no increase in bleeding. These results have been replicated in some registries, [14] but other larger ones have found no reduction in events with abciximab when clopidogrel pretreatment was given $[15,16]$. As regards bleeding risk, whereas this is clearly increased with abciximab in some registries, [17] in others this is not the case $[14,16,18]$. All registries clearly demonstrate the prognostic importance of shock and of obtaining adequate flow, as well as the need to reduce bleeding complications [15, 19-21]

Table 6 Events at 6 months by antithrombotic treatment group

\begin{tabular}{|c|c|c|c|c|c|c|c|}
\hline & $\begin{array}{l}\text { Nothing } \\
n=93\end{array}$ & $\begin{array}{l}\text { UFH } \\
n=153\end{array}$ & $\begin{array}{l}\text { UFH }+ \text { Abcx } \\
n=44\end{array}$ & $\begin{array}{l}\text { Abcx } \\
n=65\end{array}$ & $\begin{array}{l}\text { Bivalirudin } \\
n=24\end{array}$ & $\begin{array}{l}\text { Enoxaparin } \\
n=18\end{array}$ & $p$ \\
\hline Death & $9(9.6)$ & $10(6.5)$ & $5(11.4)$ & $5(7.7)$ & $2(8.3)$ & $1(5.5)$ & 0.4 \\
\hline Cardiac death & $8(8.6)$ & $9(5.9)$ & $5(11.4)$ & $4(6.1)$ & $2(8.3)$ & 0 & 0.3 \\
\hline Infarction & $1(1)$ & $3(1.9)$ & $2(4.5)$ & $1(1.5)$ & $3(12.5)$ & 0 & 0.04 \\
\hline Def./probable thrombosis & $2(2.1)$ & $7(4.6)$ & $1(2.2)$ & $2(3)$ & $3(12.5)$ & 0 & 0.08 \\
\hline BARC > 1 bleeding & $10(10.7)$ & $10(6.5)$ & $3(6.8)$ & $12(18.5)$ & $1(4.2)$ & $2(11.1)$ & 0.01 \\
\hline BARC $>2$ bleeding & $5(5.4)$ & $2(1.3)$ & 0 & $6(9.2)$ & 0 & $1(5.5)$ & 0.01 \\
\hline Brain hemorrhage & $3(3.2)$ & 0 & 0 & $1(1.5)$ & 0 & $1(5.5)$ & 0.1 \\
\hline Revascularization & 0 & $3(1.9)$ & $1(2.2)$ & $2(3)$ & 0 & 0 & 0.3 \\
\hline Stroke & $1(1)$ & 0 & 0 & $1(1.5)$ & 0 & 0 & 0.7 \\
\hline
\end{tabular}


Table 7 Independent predictors of BARC $>1$ bleeding

\begin{tabular}{llll}
\hline Variable & OR & $95 \% \mathrm{Cl}$ & $\mathrm{P}$ \\
\hline Femoral access & 3.30 & $1.3-8.3$ & 0.004 \\
Abciximab infusion & 2.26 & $1.02-5$ & 0.04 \\
Age $>$ 75 years & 2.3 & $0.95-5.62$ & 0.07 \\
\hline
\end{tabular}

Our study reflects this lack of consensus regarding antithrombotic therapy in rescue angioplasty, because although fibrinolysis treatment was very uniform, there was great variability in terms of anticoagulant and IIb/ IIIa inhibitor use in RA. We also found a lack of correlation between CRUSADE score and the incidence of bleeding. The context of RA and the particular treatment combinations seem to make this score less valid.

The rate of major bleeding in recent fibrinolysis studies was $7.5 \%$ in STREAM [3] and $1.7 \%$ in FAST-MI [22]. In the REACT study, the major bleeding rate was $0.6 \%$ and the minor bleeding rate $22.9 \%$ [7]. In this study, heparin sodium was administered in fibrinolysis and during rescue angioplasty, and abciximab was used in $43.4 \%$ of rescue angioplasties. Among patients who experienced bleeding, 69\% had been given abciximab, although this difference was not statistically significant compared with the rest of the patients. As regards mortality, in the RA arm in the REACT study, overall mortality at 6 months was $6.2 \%$, and age and diabetes were identified as predictors of mortality [7]. In the MERLIN study, one-month mortality in the RA arm was $9.8 \%$, and anterior infarction was the only predictor of mortality [6]. The mortality rate in these studies is comparable to the rate found in our study, although cardiogenic shock was an exclusion criterion in the trials. These results suggest potencial relevant differences in patients characteristics as it is commonly observed between randomized trials and observational registries, furthermore if performed in different time. Anterior infarction and age were likewise predictive factors for mortality.

Attention must be drawn to the time elapsed between thrombolysis and RA. Bearing in mind that the indication arose because of ineffective thrombolysis, a median of $170 \mathrm{~min}$ is very high, because if the indication should be established by $60 \mathrm{~min}$ post-thrombolysis, this represents a delay of almost another $2 \mathrm{~h}$ until RA. It should be noted that radial access was not used in most cases in this registry, despite the known higher bleeding risk of

Table $\mathbf{8}$ Independent predictors of mortality

\begin{tabular}{llll}
\hline Variable & OR & $95 \% \mathrm{Cl}$ & $\mathrm{P}$ \\
\hline Cardiogenic shock & 60.7 & $13.5-272$ & $<0.001$ \\
Age $>75$ years & 6.5 & $1.8-23.3$ & 0.003 \\
Anterior location & 6.2 & $1.5-24.8$ & 0.005 \\
\hline
\end{tabular}

these patients. In fact, femoral access combined with abciximab use, especially if post-RA infusion was involved, raised the bleeding risk considerably. Finding fewer bleeding episodes without the disadvantage of more ischemic events when abciximab was used in bolus form only, compared with additional infusion use, is thought-provoking. It is also interesting to note the $42 \%$ thrombus aspiration rate, despite previous thrombolysis. Although no antithrombotic regimen proved to be an independent predictor of ischemic events, bivalirudin use was associated with the highest stent thrombosis rate.

\section{Limitations}

The most obvious limitation is non-randomization for the different antiplatelet and anticoagulation regimens employed in RA. There was likewise no randomization for other aspects of the procedure, such as radial or femoral access. A randomized study would be particularly difficult in this context. In fact, apart from the occasional small study addressing abciximab use, no randomized trials were attempted during the years when RA was much more common, and they are even less likely now. This was a multicenter, consecutive registry, which makes the results more valuable and robust. Nevertheless, between-group comparisons are clearly subject to bias. The size of the groups precludes adjustment by treatment propensity score. The sample could have been larger, but this would have been difficult because the RA caseload has decreased greatly with the more widespread use of primary angioplasty. Data were not monitored off-site, because this was beyond our means. The comparability of results with previous trials on the topic, specifically with the MERLIN trial, [6] could be limited by differences in population profile. As mentioned before, the 30-day mortality was similar between our registry and this trial, despite the exclusion of cardiogenic shock in the later. The observational and more recent nature of our registry may account for these differences.

\section{Conclusions}

Antithrombotic treatment regimens during rescue angioplasty procedures vary greatly, although not adding any new drugs, and using UFH $70 \mathrm{U} / \mathrm{kg}$ alone, are the most predominant. The study did not identify any antithrombotic treatment variable independently related to mortality to any significant extent, but abciximab infusion and femoral access were associated with more bleeding risk. Therefore, in situations of rescue angioplasty, combining these two strategies should be avoided as far as possible. Considering the incidence of events in this observational study, we think it would be advisable for a prospective study to be conducted, to try to establish the safest, most effective antithrombotic treatment regimen in rescue angioplasty. 


\section{Abbreviations}

BARC: Bleeding academic research consortium; MI: Myocardial infarction; RA: Rescue angioplasty; UFH: Unfractionated heparin

\section{Acknowledgements}

Not applicable.

\section{Funding}

No funding was required for this study.

\section{Availability of data and materials}

The datasets used and/or analysed during the current study are available from the corresponding author on reasonable request.

\section{Authors' contributions}

JMTH, MSS, TGC, JRR were involved in study design, data analysis, manuscript writing, review and approval. MTA, FGC, ESL, JABR, JPR, VMY, ML, JRR were involved in data collection, data analysis, review and approval of manuscript. All authors have read and approved the submitted manuscript.

\section{Ethics approval and consent to participate}

The registry was approved by the respective ethics committees of the participating centers as listed in first page and was in compliance with the Helsinki Declaration. All patients provided written informed consent for their clinical data to be used in a strictly anonymous way.

\section{Consent for publication}

Not applicable.

\section{Competing interests}

The authors declare that they have no competing interests.

\section{Publisher's Note}

Springer Nature remains neutral with regard to jurisdictional claims in published maps and institutional affiliations.

\section{Author details \\ ${ }^{1}$ Servicio de Cardiología, Unidad de Hemodinámica y Cardiología Intervencionista, Hospital Universitario Marqués de Valdecilla, Valdecilla Sur, 1a Planta, 39008 Santander, Spain. ${ }^{2}$ Servicio de Cardiología, H de Galdakao, Vizcaya, Spain. ${ }^{3}$ Servicio de Cardiología, H. de Donostia, San Sebastian, Spain. ${ }^{4}$ Servicio de Cardiología, H. Clínico de Valladolid, Valladolid, Spain. ${ }^{5}$ Servicio de Cardiología, H. la Fé de Valencia, Valencia, Spain. '5ervicio de Cardiología, H. Carlos Haya de Malaga, Malaga, Spain. ${ }^{7}$ Servicio de Cardiología, H. General de Alicante, Alicante, Spain. ${ }^{8}$ Servicio de Cardiología, H. Clinic de Barcelona, Barcelona, Spain.}

Received: 9 January 2017 Accepted: 20 July 2017

Published online: 01 August 2017

\section{References}

1. Steg PG, James SK, Atar D, Badano LP, Blömstrom-Lundqvist C, Borger MA, Di Mario C, Dickstein K, Ducrocq G, Fernandez-Aviles F, Gershlick AH, Giannuzzi P, Halvorsen S, Huber K, Juni P, Kastrati A, Knuuti J, Lenzen MJ, Mahaffey KW, Valgimigli M, van 't Hof A, Widimsky P, Zahger D. ESC Guidelines for the management of acute myocardial infarction in patients presenting with ST-segment elevation. Task Force on the management of ST-segment elevation acute myocardial infarction of the European Society of Cardiology (ESC). Eur Heart J. 2012:33:2569-619.

2. Windecker $S$, Kolh P, Alfonso F, Collet JP, Cremer J, Falk V, Filippatos G, Hamm C, Head SJ, Jüni P, Kappetein AP, Kastrati A, Knuuti J, Landmesser U, Laufer G, Neumann FJ, Richter DJ, Schauerte P, Sousa Uva M, Stefanini GG, Taggart DP, Torracca L, Valgimigli M, Wijns W, Witkowski A. 2014 ESC/EACTS guidelines on myocardial revascularization: the task force on myocardial revascularization of the European Society of Cardiology (ESC) and the European Association for Cardio-Thoracic Surgery (EACTS). Developed with the special contribution of the European Association of Percutaneous Cardiovascular Interventions (EAPCI). Eur heart J 2014;35:2541-619.

3. Armstrong PW, Gershlick AH, Goldstein P, Wilcox R, Danays T, Lambert Y, Sulimov V, Rosell Ortiz F, Ostojic M, Welsh RC, Carvalho AC, Nanas J, Arntz HR, Halvorsen S, Huber K, Grajek S, Fresco C, Bluhmki E, Regelin A,
Vandenberghe K, Bogaerts K, Van de Werf F, STREAM Investigative Team. Fibrinolysis or primary $\mathrm{PCl}$ in ST-segment elevation myocardial infarction. N Engl J Med. 2013;368:1379-87.

4. Bonnefoy E, Steg PG, Boutitie F, Dubien PY, Lapostolle F, Roncalli J, Dissait F, Vanzetto G, Leizorowicz A, Kirkorian G, Investigators CAPTIM, Mercier C, McFadden EP, Touboul P. Comparison of primary angioplasty and prehospital fibrinolysis in acute myocardial infarction (CAPTIM) trial: a 5-year follow-up. Eur Heart J. 2009;30:1598-606.

5. Cantor WJ, Fitchett D, Borgundvaag B, Ducas J, Heffernan M, Cohen EA, Morrison LJ, Langer A, Dzavik V, Mehta SR, Lazzam C, Schwartz B, Casanova A, Goodman SG. TRANSFER-AMI trial investigators. Routine early angioplasty after fibrinolysis for acute myocardial infarction. N Engl J Med. 2009;360:2705-18.

6. Sutton AG, Campbell PG, Graham R, Price DJ, Gray JC, Grech ED, Hall JA, Harcombe AA, Wright RA, Smith RH, Murphy JJ, Shyam-Sundar A, Stewart MJ, Davies A, Linker NJ, de Belder MA. A randomized trial of rescue angioplasty versus a conservative approach for failed fibrinolysis in ST-segment elevation myocardial infarction: the Middlesbrough early revascularization to limit INfarction (MERLIN) trial. J Am Coll Cardiol. 2004:44:287-96.

7. Gershlick AH, Stephens-Lloyd A, Hughes S, Abrams KR, Stevens SE, Uren NG, de Belder A, Davis J, Pitt M, Banning A, Baumbach A, Shiu MF, Schofield P, Dawkins KD, Henderson RA, Oldroyd KG, Wilcox R, REACT trial investigators. Rescue angioplasty after failed thrombolytic therapy for acute myocardial infarction. N Engl J Med. 2005;353:2758-68.

8. Wijeysundera HC, Vijayaraghavan R, Nallamothu BK, Foody JM, Krumholz HM, Phillips CO, Kashani A, You JJ, Tu JV, Ko DT. Rescue angioplasty or repeat fibrinolysis after failed fibrinolytic therapy for ST-segment myocardial infarction: a meta-analysis of randomized trials. J Am Coll Cardiol. 2007;49:422-30.

9. Albarran A, Sanchis J, Mauri J, Pinar E, Baz JA. Angioplastia de rescate, cateterismo sistemático tras fibrinolisis y angioplastia primaria después de 12 horas. Impacto en la estancia hospitalaria y en el pronóstico. Rev Esp Cardiol 2009;Suppl 9:54C-61C.

10. Cutlip DE, Windecker S, Mehran R, Boam A, Cohen DJ, van Es GA, Steg PG, Morel MA, Mauri L, Vranckx P, McFadden E, Lansky A, Hamon M, Krucoff MW, Serruys PW. Academic research consortium. Clinical endpoints in coronary stent trials: a case for standardized definitions. Circulation. 2007;115:2344-51.

11. Mehran R, Rao SV, Bhatt DL, Gibson CM, Caixeta A, Eikelboom J, Kaul S, Wiviott SD, Menon V, Nikolsky E, Serebruany V, Valgimigli M, Vranckx P, Taggart D, Sabik JF, Cutlip DE, Krucoff MW, Ohman EM, Steg PG, White H. Standardized bleeding definitions for cardiovascular clinical trials: a consensus report from the bleeding academic research consortium. Circulation. 2011;123:2736-47.

12. Kadakia MB, Rao SV, McCoy L, Choudhuri PS, Sherwood MW, Lilly S, Kobayashi T, Kolansky DM, Wilensky RL, Yeh RW, Giri J. Transradial versus transfemoral access in patients undergoing rescue percutaneous coronary intervention after fibrinolytic therapy. J Am Coll Cardiol Intv. 2015;8:1868-76.

13. Petronio AS, Musumeci G, Limbruno U, De Carlo M, Baglini R, Paterni G, Grazia Delle Donne M, Caravelli P, Nardi C, Mariani M. Abciximab improves 6-month clinical outcome after rescue coronary angioplasty. Am Heart J. 2002;143:334-41.

14. Gruberg L, Suleiman M, Kapeliovich M, Hammerman H, Grenadier E, Boulus M, Amikam S, Markiewicz W, Beyar R. Glycoprotein Ilb/llla inhibitors during rescue percutaneous coronary intervention in acute myocardial infarction. J Invasive Cardiol. 2006;18:59-62.

15. De Felice F, Fiorilli R, Parma A, Musto C, Nazzaro MS, Confessore P, Scappaticci M, Violini R. One-year clinical outcome of patients treated with or without abciximab in rescue coronary angioplasty. Int J Cardiol. 2013:163:294-8

16. Belle L, Fourny M, Reynaud T, Hammer L, Vanzetto G, Labarère J. RENAURESURCOR study investigators. Efficacy and safety of glycoprotein Ilb/llla receptor antagonists for patients undergoing percutaneous coronary intervention within twelve hours of fibrinolysis. Catheter Cardiovasc Interv. 2011;78:376-84.

17. Jong P, Cohen EA, Batchelor W, Lazzam C, Kreatsoulas C, Natarajan MK, Strauss BH. Bleeding risks with abciximab after full-dose thrombolysis in rescue or urgent angioplasty for acute myocardial infarction. Am Heart J. 2001;141:218-25.

18. Shugman IM, Hsieh V, Cheng S, Parikh D, Tobing D, Wouters $N$, van der Vijver R, Lo Q, Rajaratnam R, Hopkins AP, Lo S, Leung D, Juergens CP, French JK. Safety and efficacy of rescue angioplasty for 
ST-elevation myocardial infarction with high utilization rates of glycoprotein Ilb/llla inhibitors. Am Heart J. 2012;163:649-56.

19. De Felice F, Fiorilli R, Parma A, Musto C, Nazzaro MS, Stefanini GG, Caferri G, Violini R. Comparison of one-year cardiac events with drug-eluting versus bare metal stent implantation in rescue coronary angioplasty. Am J Cardio. 2011;107:210-4.

20. Sohal M, Foo F, Sirker A, Rajani R, Khawaja MZ, Pegge N, Hatrick R, Kneale B, Signy M, Holmberg S, de Belder A, Hildick-Smith D. Rescue angioplasty for failed fibrinolysis-long-term follow-up of a large cohort. Catheter Cardiovasc Interv. 2011;77:599-604.

21. Pérez-Berbel P, Valencia J, Ruiz-Nodar JM, Pineda J, Bordes P, Mainar V Sogorb F. Rescue angioplasty: characteristics and results in a single-center experience. J Interv Cardiol. 2011;24:42-8.

22. Danchin N, Coste P, Ferrières J, Steg PG, Cottin Y, Blanchard D, Belle L, Ritz B, Kirkorian G, Angioi M, Sans P, Charbonnier B, Eltchaninoff $H$, Guéret P, Khalife K, Asseman P, Puel J, Goldstein P, Cambou JP, Simon T. Intervention with primary percutaneous coronary intervention for ST-segment elevation acute myocardial infarction: data from the French registry on acute ST-elevation myocardial infarction (FAST-MI). Circulation. 2008;118:268-76.

Submit your next manuscript to BioMed Central and we will help you at every step:

- We accept pre-submission inquiries

- Our selector tool helps you to find the most relevant journal

- We provide round the clock customer support

- Convenient online submission

- Thorough peer review

- Inclusion in PubMed and all major indexing services

- Maximum visibility for your research

Submit your manuscript at www.biomedcentral.com/submit
Biomed Central 